\title{
MECHANICAL PROPERTIES OF POLYMER-MATRIX CELLULOSE-BASED COMPOSITE MATERIALS
}

\author{
MEHANSKE LASTNOSTI KOMPOZITNIH MATERIALOV S \\ POLIMERNO MATRICO NA OSNOVI CELULOZE
}

\author{
Necmi Duşunceli*, Seckin Surme \\ Aksaray University, Department of Mechanical Engineering, 68100 Aksaray, Turkey \\ Prejem rokopisa - received: 2019-09-17; sprejem za objavo - accepted for publication: 2019-11-08
}

doi:10.17222/mit. 2019.223

\begin{abstract}
This study focuses on composite cardboard panels, determining their mechanical properties. The panels were manufactured of a minced waste-paper-based composite material. First, four types of mixture were prepared using minced-material composite cardboards with different ratios of polyethylene (PE). Second, the mixtures were compressed and heated in a mold, and then a composite cardboard panel (CCP), 7-mm thick, was produced. In the third stage, tensile, three-point-bending, nail-pulling and water-absorption tests were applied to specimens of different CCPs. Mechanical tests were conducted using a tensile testing machine in accordance with ASTM 1037. In this study, the mechanical behaviors of the CCPs associated with the added PE were investigated. Observations showed that the presence of PE enhanced the mechanical strength of the CCPs and resulted in an increase in the nail-pulling-load and water-absorption resistance. The investigation was extended to conventional wooden panels (oriented strand board and fiberboard), which were exposed to the same tests. The experimental data demonstrated that the strength of the new product was higher than that of the conventional wooden panels. The results suggest that CCPs can be used as an alternative to wooden panels.
\end{abstract}

Keywords: composite materials, mechanical properties, polymer, waste treatment, recycling

Vštudiji so se avtorji osredotočili na kompozitne kartonske panele (plošče) in določitev njihovih mehanskih lastnosti. Paneli so bili izdelani iz sesekljanega oz. narezanega kompozitnega materiala na osnovi odpadnega papirja. Najprej so izdelali štiri vrste mešanic iz sesekljanega kartona in različno količino polietilena (PE). Mešanice so nato stisnili, segreli in oblikovali v $7 \mathrm{~mm}$ debele kompozitne kartonske plošče (CCP). Iz izdelanih kompozitnih kartonskih plošč so izrezali preizkušance za tritočkovni upogibni preizkus, trgalni preizkus in preizkus absorpcije vode. Mehanske preizkuse so izvedli na univerzalnem trgalnem stroju v skladu s standardom ASTM 1037. Analize preizkusov so pokazale, da dodatek polietilena izboljša mehansko trdnost izdelanih kompozitov in poveča njihovo odpornost proti absorpciji vode. Raziskavo so avtorji dodatno razširili še na testiranje lesenih kompozitnih panelov (iz sekancev in vlaken). Nove kompozitne kartonske plošče imajo $\mathrm{v}$ primerjavi s konvencionalnimi lesenimi ploščami večjo trdnost, zato bi se lahko uporabljale kot njihova alternativa.

Ključne besede: kompozitni materiali, mehanske lastnosti, polimer, obdelava odpadkov, recikliranje

\section{INTRODUCTION}

Solid waste is classified as organic and inorganic materials. The latter comprise glass, ceramics, and metals such as iron; especially aluminum, copper and a small amount of zinc are used for packaging materials. Solid waste has the most impact in terms of polluting the environment and the solution to this problem is the recycling of these materials, which has been investigated for many years. Additionally, being extensively used and difficult to recycle, plastic materials are a huge problem in terms of their effect on the environment. ${ }^{1-4}$

Composite cardboards are widely used as the storage material in the beverage and food industry. These materials also constitute a serious environmental problem since there are limitations to the recycling of this waste. In terms of reducing environmental pollution, it is important to produce a product from used composite beverage containers in an economical and appropriate manner. ${ }^{5}$

*Corresponding author's e-mail:

ndusunceli@aksaray.edu.tr (Necmi Duşunceli)
Multilayer composite packaging is made from a combination of different materials such as a polymeric matrix, aluminum film and paper, and it is widely used for packaging food and beverages. Composite packages can be divided into three main types according to their component proportions: paper-cardboard, metal and plastic composite packages. ${ }^{6-8}$ Multilayer composite cardboard contains paper and reinforcement elements in a mixture of polymeric material and aluminum as the matrix elements in different proportions. This type of composite material generally contains $75 \%$ of paper, $20 \%$ of polyethylene and $5 \%$ of aluminum and has been used as a common raw material for the packaging industry for forty years.

The recycling of composite cardboard is difficult due to its multilayer construction and it is one of the fundamental problems of the modern world. The European Union waste-management policies are based on the waste-management hierarchy and the producer-responsibility principle. The primary priority of this hierarchy is to prevent waste in the production phase and reduce the amount of waste and hazard level. The second 
priority is to ensure that non-recyclable waste is incinerated while other waste is safely stored until its re-use, recycling or use in energy recovery. Although there are many methods for recycling composite beverage packages, the most convenient and economical method is to use them in the manufacturing of panels. ${ }^{9-12}$

In the traditional sense, cardboard has different structures, ranging from a single thick paper sheet to multiple corrugated sheets. The layer structure was shown to significantly affect the stiffness and durability of cardboard at a high bearing load. The definition of paper and cardboard varies from country to country and is generally shaped by customer demand and traditions. Cardboard is the basic element for product boxes and packages. Although cardboard is associated with the production of packaging, some of the products created from recycled materials are also utilized as structural elements in buildings, e.g., the walls, ceilings, roofs and floors in temporary-accommodation buildings. ${ }^{13}$

The basic cardboard types are given below:

The corrugated paper panel was patented in England in 1875. This product consists of one grooved corrugated plate and one or two straight linear plates. Its structural characteristics made it popular in the packaging sector as a shipping box. ${ }^{14-16}$ Honeycomb-paper panels evolved from corrugated-paper panels. These sandwich panels consist of polygonal cells and have considerable advantages over other products due to their lightweight and superior strength properties. It is quite easy to process, recycle, reuse and biodegrade. Due to such advantageous features, it is used in many different sectors. It has a widespread use as a core element in interior walls, ceilings, partition walls, furniture panels and coating surfaces. On the other hand, many artists and architects make use of the paper panels in the honeycomb form in their work. ${ }^{17-20}$

Among the various types of cardboard, composite cardboards are of particular interest because of their enhanced mechanical properties and preservation of beverages. Composite cardboard designed for recycling can be mainly used in furniture making, construction, aesthetic design, packaging and transportation. Composite-cardboard panels (CCPs), whose main and matrix material is composite cardboard, are capable of bearing high loads in construction. In addition, the damping and insulation properties of CCPs make them suitable for a range of different uses. ${ }^{21-27}$

In this study, four different CCPs were produced using composite beverage packages and their mechanical properties were determined. A paper composite sheet normally consists of six layers. One of these layers, polyethylene (PE), improves the strength of the paper composite material. Since the focus of the investigation was on the effects of a PE addition on the mechanical properties of CCPs, the mechanical characteristics of CCPs were analyzed as a function of added PE. Four different panels were produced and three amounts of PE were added to the shredded paper blend. The mechanical and physico-mechanical properties of the panels were investigated using tensile, three-point bending, nail-pull and water-absorption tests.

\section{EXPERIMENTAL PART}

\subsection{Preparation of CCPS}

Four different panels were manufactured and then specimens were extracted from them. The dimensions of the panels were $(200 \times 200 \times 7) \mathrm{mm}$. The first set of panels was manufactured from minced composite cardboard without any additive. Composite cardboard normally includes 20 w/\% PE; therefore, the PE share in the panel was $20 \mathrm{w} / \%$. To the second set of panels, $30 \mathrm{w} / \%$ PE was added. The third and fourth sets of panels were produced by adding $40 \mathrm{w} / \%$ and $50 \mathrm{w} / \% \mathrm{PE}$, respectively. ${ }^{28,29}$

First, all the panels were prepared of minced composite cardboard and the determined PE amounts; then, the mixtures were placed into a cold mold. After exposure to pressure in the cold mold, the mold was heated to the melting point of $\mathrm{PE}$ and the mixture was kept in it for over an hour. $5 w / \%$ of aluminum provides an effective conduction of heat in and out of the material. At the same time, aluminum ensures the rigidity of the panel. The specimens were extracted from the CCPs according to ASTM 1037. ${ }^{30}$

The mechanical properties of the CCPs were determined through standard tests. Mechanical tests were conducted using a universal testing machine Shimadzu Autograph AG-IC $(50 \mathrm{kN})$ equipped with an electromechanical sensor for the control of longitudinal strains. The tensile force was measured with a $5-\mathrm{kN}$ load cell. Engineering stress $\sigma$ was calculated as the tensile force divided by the cross-sectional area of undeformed specimens. The experimental program involved four series of tests, each test being performed on a new specimen and repeated five times.

Observations revealed good reproducibility of the measurements: deviations between the stresses measured on different specimens did not exceed $3 \%$. All the tests were performed at room temperature. Then, comparisons between a conventional wooden board (CWB) and the CCPs were made for all the test results.

\subsection{Preparation of test specimens}

Tensile specimens were obtained from CCPs. Figure 1 gives the dimensions of the tensile-test specimens and Figure 2 presents a photograph of these specimens. The average thickness of the specimens was $7 \mathrm{~mm}$. Five specimens were prepared for each set $(20 \mathrm{w} / \%$ PE, $30 w / \%$ PE, $40 w / \%$ PE and $50 w / \%$ PE) and an oriented strand board (OSB) and fiberboard panel (FBP) were also tested. Specimens were stretched at a crosshead 


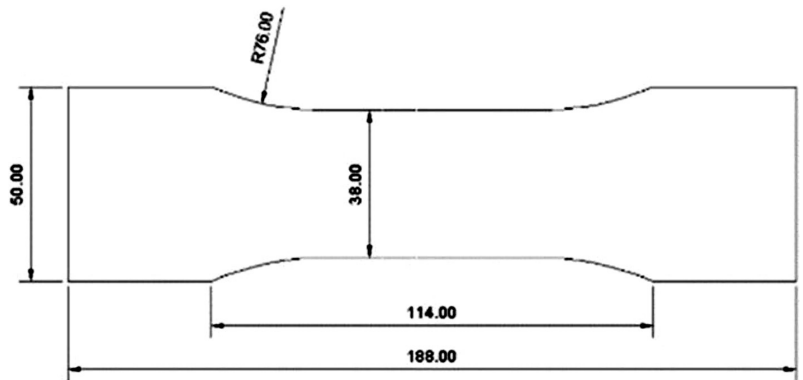

Figure 1: Dimensions of a tensile specimen

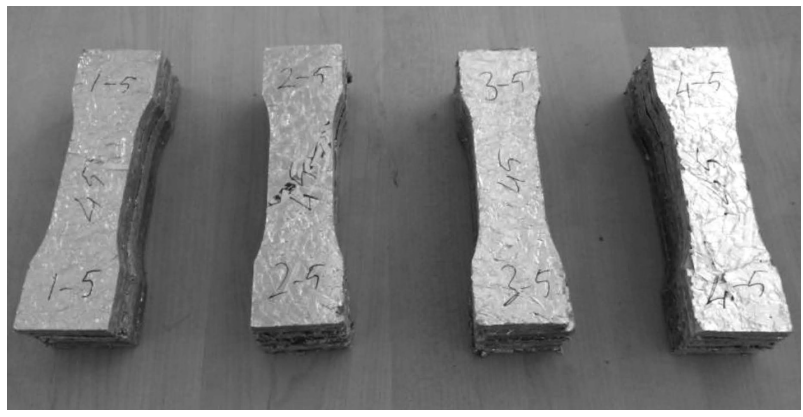

Figure 2: Tensile specimens

speed of $\dot{d}=4 \mathrm{~mm} / \mathrm{min}$. The tests were terminated when the ultimate tensile stress values decreased by $20 \%$.

Three-point bending specimens were prepared in accordance with the ASTM D 1037-99 standard $^{30}$ as shown in Figures 3 and 4. Five specimens were prepared for each set. The three-point bending test was performed at a crosshead speed of $\dot{d}=4 \mathrm{~mm} / \mathrm{min}$. The tests were terminated when the maximum load values decreased by $20 \%$.

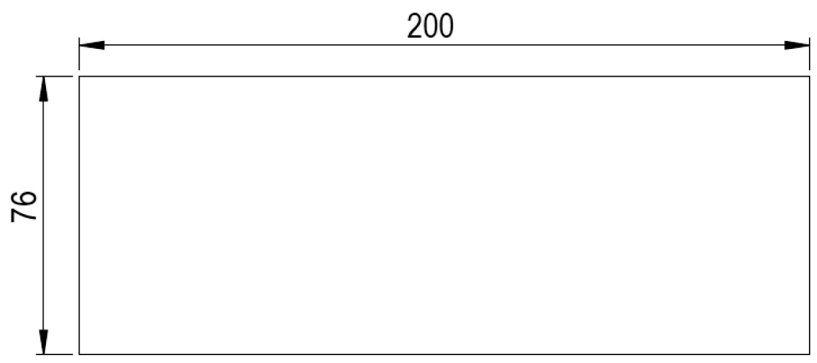

Figure 3: Dimensions of a three-point bending specimen

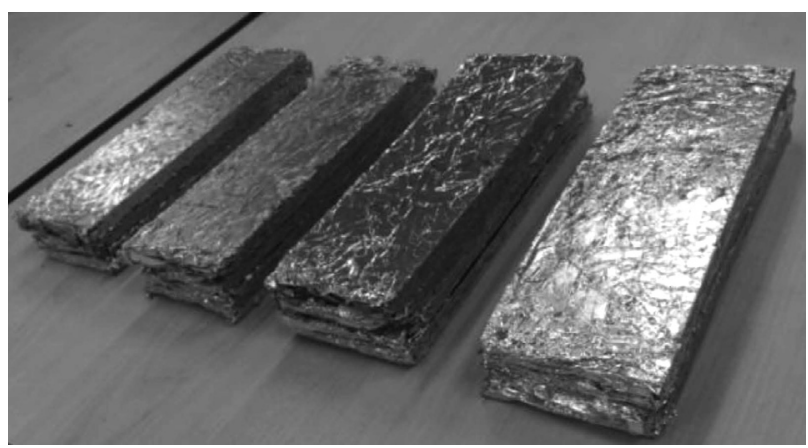

Figure 4: Three-point bending specimens

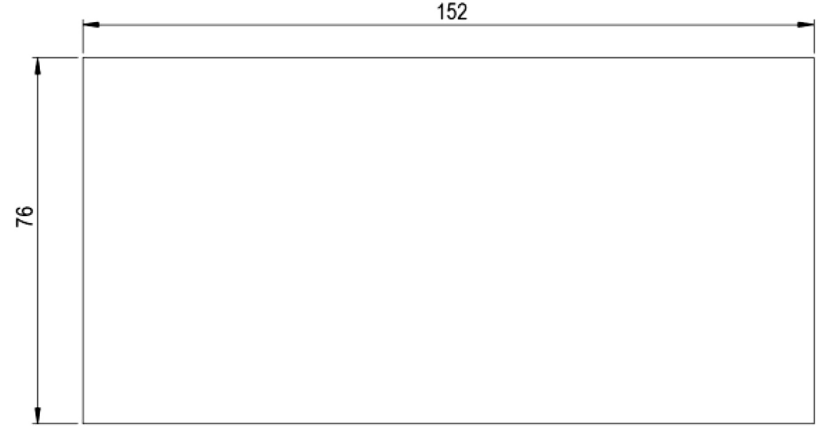

Figure 5: Dimension of the nail-pulling specimens

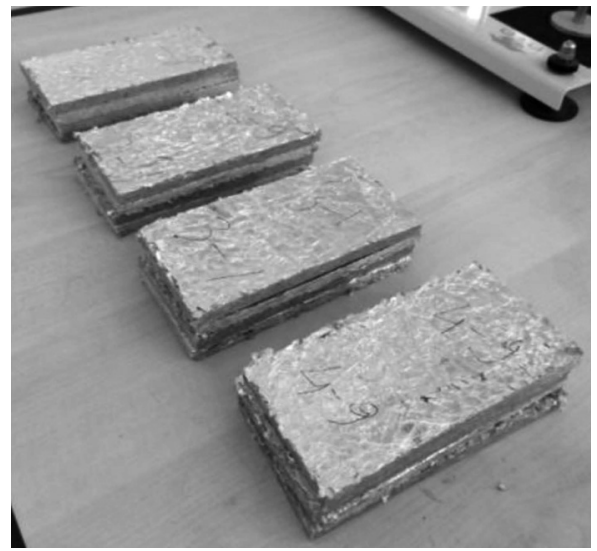

Figure 6: Nail-pulling specimens

The standards published by ASTM include the test methods for clear wooden materials and also for fiberboard and particleboard. ASTM D1037 specifies the use of the same test fixture for conducting nail- and screwwithdrawal tests on wood-based product specimens. Nail-withdrawal specimens should be at least $76 \times 152 \mathrm{~mm}$ and have the as-manufactured thickness. A nail is driven perpendicularly into the face of the wood specimen, leaving at least $13 \mathrm{~mm}$ of the shank exposed. Screw-withdrawal tests only differ in the dimensions of the specimens: for face-withdrawal tests, they should be at least $76 \times 100 \mathrm{~mm}$ and $2.54 \mathrm{~mm}$ in thickness, while edge-withdrawal specimens should be at least $76 \times 152$

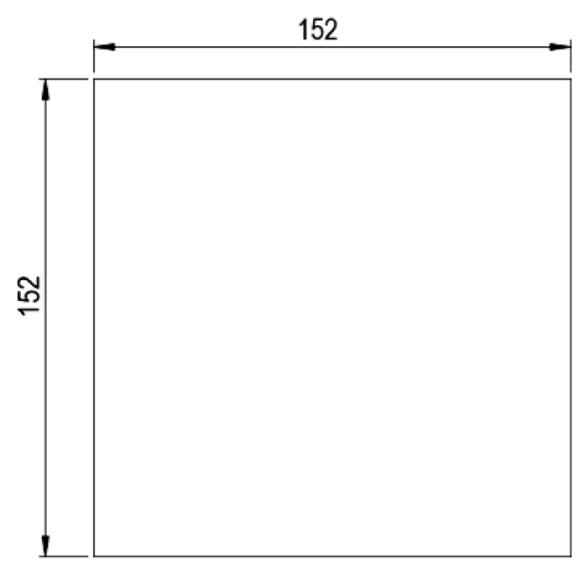

Figure 7: Dimension of water-absorption specimens 
$\mathrm{mm}$ and have the as-manufactured thickness. Nail-headpulling tests are very similar to withdrawal tests. All the tests are conducted at a crosshead speed of $\dot{d}=1.5$ $\mathrm{mm} / \mathrm{min} .{ }^{30}$ The nail-pulling test specimens are presented in Figures 5 and $\mathbf{6}$.

Water absorption is used to determine the amount of water absorbed under specified conditions. The factors affecting the water absorption include the type of plastic, additives used, temperature and length of exposure. Water-absorption test specimens are shown in Figure 7. The test specimens prepared for the water-absorption test had an average thickness of $7 \mathrm{~mm}$ and dimensions of 152 $152 \mathrm{~mm}^{30}$

\section{RESULTS}

The CCPs fabricated from the composite-cardboard waste had better tensile properties than the equivalent wood-based structural materials including OSB and FBP. The average of the tensile-test values and the maximum stress were taken for five specimens from each set. The stress-strain curves for the panels are shown in Figure 8.

It can be observed that the tensile strength of the CCPs increased with the increasing amount of PE. Additionally, the toughness of the materials increased with the increase in the amount of PE. When the strength of the CCPs was compared with that of conventional products, i.e., OSB and FBP, the strength of the new materials was significantly higher than that of the conventional wood-based materials. The tensile-strength results are presented in Table 1.

Table 1: Tensile strength of the CCPs, OSB and FBP

\begin{tabular}{|c|c|c|c|}
\hline $\begin{array}{c}\text { Type of } \\
\text { panel }\end{array}$ & $\begin{array}{c}\text { Rupture stress } \\
(\mathrm{MPa})\end{array}$ & $\begin{array}{c}\text { Rupture } \\
\text { strain }(\%)\end{array}$ & $\begin{array}{c}\text { Young's modulus } \\
(\mathrm{MPa})\end{array}$ \\
\hline $20 w / \%$ PE & 8.19 & 0.87 & 1353.63 \\
\hline $30 w / \%$ PE & 9.58 & 1.22 & 1182.26 \\
\hline $40 w / \%$ PE & 10.86 & 1.28 & 1137.93 \\
\hline $50 w / \%$ PE & 12.98 & 2.05 & 1126.14 \\
\hline OSB & 2.58 & 0.30 & 973.85 \\
\hline FBP & 6.67 & 0.56 & 385.58 \\
\hline
\end{tabular}



Figure 8: Stress-strain curves for the CCPs, OSB and FBP
For the first sample containing $20 w / \%$ of PE, the maximum tensile strength was approximately three times higher than that of the OSB. Furthermore, the tensile stress and strain also increased depending on the amount of PE. However, the modulus of elasticity decreased with the increase in the amount of PE.

The ultimate tensile stress $\left(\sigma_{\max }\right)$ of the CCP increased remarkably with an addition of $10 w / \%$ of PE to each set of specimens (Figure 8). The CCPs with (30, 40 and 50) $w / \%$ of PE had a greater stiffness than the OSB and FBP specimens. Young's modulus of the CCP with $20 w / \%$ of PE was 1.5 times greater than that of OSB and 3.5 times greater than that of FBP. The stiffness of CCP increased with the addition of PE (Figure 8). The mechanical behavior of CCP was non-linear, exhibiting viscoelastic properties due to the characteristics of polymeric materials.

A further test was conducted to assess the influence of the bending load on the mechanical behavior of CCPs under monotonic loading. In each test, a specimen was loaded with a crosshead speed of $\dot{d}=4 \mathrm{~mm} / \mathrm{min}$ until rapture. This series included eight tests performed on the specimens containing (20, 30, 40 and 50) w/\% of PE. Furthermore, a three-point bending test was performed on the OSB and FBP specimens to compare their bending properties with those of the CCP specimens.

The observations taken during the three-point bending tests on CCP, OSB and FBP are reported in Figure 9 where load $\mathrm{P}$ is plotted versus deflection $\delta$. This figure demonstrates that: (i) under bending, the load grows and reaches its maximum value, then, it sharply decreases; (ii) loading and deflection paths of the panels differ significantly; (iii) hysteresis energy (the area between the corresponding loading and deflection paths) strongly increases with the increase in the amount of PE.

The manufactured CCP specimens had better bending strength than the OSB and FPB specimens because the influence of the maximum viscoelasticity deflection for CCPs was substantially bigger than that for wood-based panels. The Young's modulus, rupture stress and rapture

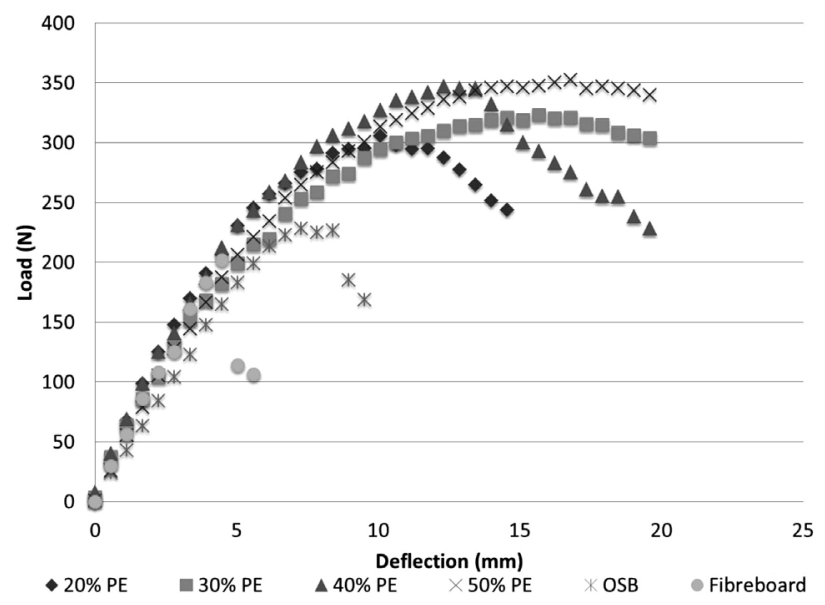

Figure 9: Load-deflection curves for the CCPs, OSB and FBP 
deflection $(\delta \max )$ at the maximum load are presented in Table 2.

Table 2: Three-point bending strength of the CCPs, OSB and FBP

\begin{tabular}{|c|c|c|c|}
\hline Type of panel & $\begin{array}{c}\text { Rupture stress } \\
\text { (MPa) }\end{array}$ & $\begin{array}{c}\text { Rupture de- } \\
\text { flection (mm) }\end{array}$ & $\begin{array}{c}\text { Young's } \\
\text { modulus (MPa) }\end{array}$ \\
\hline $20 \mathrm{w} / \%$ PE & 20.67 & 10.07 & 2690.39 \\
\hline $30 \mathrm{w} / \%$ PE & 21.88 & 15.68 & 2529.21 \\
\hline $40 \mathrm{w} / \%$ PE & 23.47 & 12.32 & 2804.37 \\
\hline $50 \mathrm{w} / \%$ PE & 23.84 & 16.79 & 2171.35 \\
\hline OSB & 15.43 & 7.27 & 1768.85 \\
\hline FBP & 13.63 & 4.48 & 2326.06 \\
\hline
\end{tabular}

In terms of the amount of PE in the mixture of CCP, the results of the three-point bending test were similar to those obtained with the tensile test.

The three-point bending strength of the CCPs increased as the PE amount in the mixture increased. Similarly, the toughness values of the materials significantly increased with the increasing amount of PE. Thus, it can be concluded that the three-point bending strength of the new products was higher than that of the conventional wooden panels, namely OSB and FBP.

The bending strength of the CCP containing $20 \mathrm{w} / \%$ of PE was approximately 1.5 times higher than that of the conventional wooden products. The increased amount of PE had a positive effect on the strength of the CCP specimens. Although Young's modulus of the CCP specimen containing $50 \mathrm{w} / \%$ of PE was lower than that of FBP, the other sets of CCP specimens had superior bending properties compared to those of OSB and FBP. The rupture deflection of the $\mathrm{CCP}$ sets was greater than that of OSB and FBP specimens.

A systematic experimental scheme for the characterization of the nail-withdrawal resistance was conducted for the CCPs. The determination of clearly defined nail-withdrawal resistance allows for the utilization of CCPs in a wide range of practical design applications. The nail-withdrawal resistance was measured for each CCP specimen in order to determine the strength variability within the panels. The nails were hammered into the center of a specimen until they reached the opposite surface of the specimen.

Table 3: Nail-pulling load of the CCPs, OSB and FBP

\begin{tabular}{|c|c|}
\hline Type of panel & $\begin{array}{c}\text { Strength of the nail pull } \\
(\mathrm{N} / \mathrm{cm})\end{array}$ \\
\hline $20 w / \% \mathrm{PE}$ & 116.05 \\
\hline $30 w / \% \mathrm{PE}$ & 140.08 \\
\hline $40 w / \% \mathrm{PE}$ & 145.08 \\
\hline $50 w / \% \mathrm{PE}$ & 164.61 \\
\hline OSB & 50.21 \\
\hline FBP & 33.47 \\
\hline
\end{tabular}

The nail-withdrawal load applied on each specimen is given in Table 3. The strength value of the fourth CCP set was three times higher than that of OSB and nearly five times higher than that of FBP. Furthermore, in- creasing the amount of PE in CCP made a notable difference in the withdrawal load of the CCP.

Before the water-absorption test, the initial thickness and weight of all the specimens were measured. Then, all the specimens were kept in containers full of pure water for two hours. After this period, the specimens were weighed again and placed back in the container for $24 \mathrm{~h}$. At the end of the test, the thickness and weight of the specimens were measured for comparison. Table 4 presents the thickness and weight of the specimens for 2-hour and 24-hour test durations.

Table 4: Water absorption of the CCPs, OSB and FBP after $2 \mathrm{~h}$ and $24 \mathrm{~h}$

\begin{tabular}{|c|c|c|c|c|}
\hline \multirow{2}{*}{$\begin{array}{c}\text { Type of } \\
\text { panel }\end{array}$} & \multicolumn{4}{|c|}{ Increment (\%) } \\
\cline { 2 - 5 } & \multicolumn{2}{|c|}{ After $2 \mathrm{~h}$} & \multicolumn{2}{c|}{ After 24 h } \\
\cline { 2 - 5 } & Weight & Thickness & Weight & Thickness \\
\hline $20 w / \%$ PE & 2.68 & 1.54 & 8.38 & 6.04 \\
\hline $30 w / \%$ PE & 2.35 & 0.80 & 6.04 & 4.04 \\
\hline $40 w / \%$ PE & 2.26 & 0.83 & 5.77 & 3.2 \\
\hline $50 w / \%$ PE & 1.74 & 0.96 & 4.49 & 3.15 \\
\hline OSB & 20.12 & 4.64 & 56.57 & 14.89 \\
\hline FBP & 20.19 & 6.59 & 58.91 & 20.04 \\
\hline
\end{tabular}

The amount of PE in CCP causes a substantial decrease in the degree of water absorption. Similarly, the increase in the thickness of CCP decreased with the increase in the amount of PE. When the amount of PE in CCP was higher than $30 \mathrm{w} / \%$, the increment of the panel thickness decreased monotonically with the increased time in water. The weight of the conventional wooden panels in the water increased rapidly during the test. The comparison between the new products and conventional wooden panels showed that the absorption of the latter was approximately ten times higher than that of the former.

\section{CONCLUSIONS}

After beverage packages are used, they become waste materials that need to be recycled in certain quantities. In this study, a CCP was produced from waste milk and juice packages. This product is important not only for its commercial value but also for its positive environmental impact and the incorporation of solid-waste recycling into the manufacturing stream. The results of the investigation were as follows:

- The tensile strength of the CCP obtained with recycling was higher than that of the conventional wooden panels. When the amount of PE in the CCP increased, the tensile strength also increased.

- The strength of the CCP during the three-point bending was higher than that of the conventional wooden panels. The increased PE amount in the mixtures improved the three-point-bending strengths of the CCP specimens. 
- According to the results of the nail-pulling test, the nail-withdrawal load for the CCP was higher compared to conventional wooden panels.

- The water absorption of the new products was significantly lower than that of the conventional wooden panels.

Based on these results, it can be concluded that cardboard made from paper-based composite materials can be used in the manufacturing of furniture, artistic production or, as an auxiliary material, in the construction industry. The product has a great potential in household applications and can become a competitive product for commercial use as well as having a wide range of benefits for the protection of the environment and conservation of natural resources.

\section{Acknowledgment}

Necmi Dusunceli acknowledges the financial support from the Aksaray University Department of Scientific Research Projects, project number 2015-074.

\section{REFERENCES}

${ }^{1}$ S. Haggar, Sustainability of Municipal Solid Waste Management, Sustainable Industrial Design and Waste Management, Chapter 5, USA 2010

${ }^{2}$ M. Xie, Q. Qiao, Q. Sun, L. Zhang, Life cycle assessment of composite packaging waste management-a Chinese case study on aseptic packaging, The International Journal of Life Cycle Assessment, 18 (2013) 3, 626-635

${ }^{3}$ M. Mehrabzadeh, F. Farahmand, Recycling of commingled plastics waste containing polypropylene, polyethylene and paper, Journal of Applied Polymer Science 80 (2001) 13, 2573-2577

${ }^{4}$ S. E. Uzun, V. Enç, F. Hoşoğlu, Waste Composite Beverage Cartons Back Conversion Methods, Journal of History, Culture and Art Research, 1 (2013) 4, 345-359

${ }^{5}$ N. Ayrilmis, Z. Candan, S. Hiziroglu, Physical and mechanical properties of cardboard panels made from used beverage carton with veneer overlay, Materials \& Design, 29 (2008) 10, 1897-1903

${ }^{6}$ H. Diehla, F. Welleb, How to determine functional barrier performance towards mineral oil contaminants from recycled cardboard, Food Packaging and Shelf Life, 5 (2015), 41-49

${ }^{7}$ S. Allaoui, Z. Aboura, M. L. Benzeggagh, Phenomena governing uni-axial tensile behaviour of paperboard and corrugated cardboard, Composite Structures, 87 (2009), 80-92

${ }^{8}$ M. Akgul, Y. Copur, C. Guler, A. Tozoglu, U. Buyuksari, Medium density fibreboard from Quercus robur, Journal of Applied Sciences, 7 (2007) 7, 1085-1087

${ }^{9}$ P. Ricciardi, E. Belloni, F. Cotana, Innovative panels with recycled materials: Thermal and acoustic performance and Life Cycle Assessment, Applied Energy, 134 (2014), 150-162

${ }^{10}$ F. E. Boafo, J. Kima, Z. Chen, Configured cavity-core matrix for vacuum insulation panel: Concept, preparation and thermophysical properties, Energy and Buildings, 97 (2015), 98-106

${ }^{11}$ E. Kurkela, Fluidized-Bed Gasification of Biomass for Syngas BTL in forest industry, Bioenergy NoE Final seminar, Brussels 2009

${ }^{12}$ K. Jayaraman, D. Bhattacharyya, Mechanical performance of woodfibre-waste plastic composite materials, Resources, Conservation and Recycling, 41 (2004) 4, 307-319
${ }^{13}$ Z. Aboura, N. Talbi, S. Allaoui, M. L.Benzeggagh, Elastic behavior of corrugated cardboard: experiments and modeling, Composite Structures, 63 (2004), 53-62

${ }^{14}$ F. Asdrubali, A. L. Pisello, F. D’Alessandro, F. Bianchi, C. Fabiani, M. Cornicchia, A. Rotili, Experimental and numerical characterization of innovative cardboard based panels: Thermal and acoustic performance analysis and life cycle assessment, Building and Environment, 95 (2016), 145-159

${ }^{15}$ A. Sahin, H. M. Tasdemir, F. A. Karabulut, M. Metin Gürü, Mechanical and Thermal Properties of Particleboard Manufactured from Waste Peachnut Shell with Glass Powder, Arabian Journal for Science and Engineering, 42 (2017) 4, 1559-1568

${ }^{16} \mathrm{~T}$. Thamae, C. Baillie, Influence of fibre extraction method, alkali and silane treatment on the interface of Agave americana waste HDPE composites as possible roof ceilings in Lesotho, Composite Interfaces, 14 (2007) 7-9, 821-836

${ }^{17}$ S. Secchi, F. Asdrubali, G, Cellai, E. Nannipieri, E. Rotili, I. Vannucchi, Experimental and environmental analysis of new sound-absorbing and insulating elements in recycled cardboard, Journal of Building Engineering, 5 (2016), 1-12

${ }^{18}$ C.-Y. Hwang, Feasibility of Manufacturing Paper-Plastic Laminates Using Waste Office Paper, Taiwan Journal For Science, 23 (2008) 1, 35-46

${ }^{19}$ J. H. Muehl, A. Krzysik, P. Chow, Composite panels made with biofiber or office wastepaper bonded with thermoplastic and/or thermosetting resin, US Department of Agriculture, Forest Service, Forest Products Laboratory, 294 (2004)

${ }^{20}$ D. Ndiaye, M. Gueye, B. Diop, Characterization, Physical and Mechanical Properties of Polypropylene/Wood-Flour Composites, Arabian Journal for Science and Engineering, 38 (2013) 1, 59-68

${ }^{21}$ A. M. Krzysik, J. H. Muehl, J. A. Youngquist, F. Franca, Medium Density Fiberboard Made from Eucalyptus Saligna, Composites and Manufactured Products, 51 (2001) 10, 47-50

${ }^{22}$ A. Hussein, R. Salim, A. Sultan, Water absorption and mechanical properties of high-density polyethylene/egg shell composite, J. Basrah Res., 37 (2011) 3A, 36-42

${ }^{23}$ N. Navaranjan, C. G. Fletcher, G. Summers, R. Parr, R. Anderson, Thermal insulation requirements and new cardboard packaging for chilled seafood exports, Journal of Food Engineering, 119 (2013), 395-403

${ }^{24}$ S. O. Adeosun, V. Gbenebor, I. Akpan, F. A. Udeme, Influence of Organic Fillers on Physicochemical and Mechanical Properties of Unsaturated Polyester Composites, Arabian Journal for Science and Engineering, 41 (2016) 10, 4153-4159

${ }^{25}$ J. H. Kwon, N. Ayrilmis, T. H. Han, Enhancement of flexural properties and dimensional stability of rice husk particleboard using wood strands in face layers, Compos. Part B, 44 (2013), 728-732

${ }^{26}$ S. Y. Lee, H. S. Yang, H. J. Kim, C. S. Jeong, B. S. Lim, J. N. Lee, Creep behavior and manufacturing parameters of wood flour filled polypropylene composites, Compos. Struct., 65 (2004), 459-469

${ }^{27}$ M. S. Ibrahim, S. M. Sapuan, A. A. Faieza, Mechanical and thermal properties of composites from unsaturated polyester filled with oil palm ash, J. Mech. Eng. Sci., 2 (2012), 133-147

${ }^{28}$ N. Dusunceli, B. Aydemir, The Effects of Loading History and Manufacturing Methods on the Mechanical Behavior of HighDensity Polyethylene, Journal of Elastomer and Plastics, 43 (2011), 451-468

${ }^{29}$ N. Dusunceli, Ö. U. Colak, The Effects of Manufacturing Techniques on Visco-Elastic and Viscoplastic Behavior of High Density Polyethylene (HDPE), Materials and Design, 29 (2008) 6, 1117-1124

${ }^{30}$ ASTM: Evaluating the properties of wood base fiber and particle panel material, in: ASTM D1037-99, American Society for Testing and Materials, West Conshohocken, PA, 1999 